\title{
COOPETITION STRATEgy AND TOURISM Business: AN EMPIRICAL INVESTIGATION OF EGYPTIAN TOURISM SMES
}

\author{
Hala Nabil Hilaly \\ Associate Professor, Tourism Studies Department \\ Faculty of Tourism and Hotels, Alexandria University
}

\begin{abstract}
Coopetition is a relatively new concept, a concept that emphasizes the simultaneous competition and cooperation between firms. As Coopetition can be useful to increase competency, as well as gain more benefits with less costs (Saraniemi and Kylanen 2010). Therefore it can be used to improve the tourism industry ability in Egypt to withstand disasters and catastrophes. This study investigates the practice of coopetition strategy in the Egyptian tourism industry, as well as discusses the co-existence of competition and cooperation within tourism companies. It also highlights the benefits of this emergent strategy on tourism business. Structured questionnaires were distributed to explore coopetition within Egyptian tourism companies' key- persons. Data was obtained from 52 small and medium sized businesses operating in Alexandria (Egypt). According to results, SMES that participated in the survey have a positive attitude related to the coopetition strategy. That is, they assess the collaboration with competitors; positively. The study concludes that the surveyed companies apply coopetition within both their functional and strategic levels.
\end{abstract}

Key words: Coopetition, strategic alliances, competition, collaboration, SMEs.

\section{Introduction}

The global environment has been changing dramatically; firms face many new challenges. There are lots of competitive pressures and risks which prevent the businesses to achieve their goals. The case is more acute in tourism industry due to its sensitivity, and complexity. Therefore in today's world, the company's ability to adopt the changes will determine its success and its sustainability or even survival. Due to competitiveness environment, many companies do not have all the resources and capabilities that are needed for competition on their own (Yami et al. 2010). More importantly, they are not also willing to take all the risks alone to strive against powerful competitors. As a result of these new conditions, companies need for new strategies in dealing with these new challenges. Consequently, first collaboration becomes very important for the companies and then, coopetition has been appeared (Schiavone and Simoni, 2011).

Coopetition is a relatively new concept, a concept that emphasizes the simultaneous competition and cooperation between firms. Coopetition is the phenomenon by which "firms in the same industry complete each other in creating markets but compete in 
dividing up markets" (Chesbrough et al., 2006, p. 87). According to this strategy, businesses can work together to realize their common goals but at the same time compete with each other along with other firms depending on conflicting benefits (Zineldin, 2004).

Although coopetition was generally used by larger companies in the past, lately small and medium sized enterprises (SMEs) realized the importance of such strategy and its possible advantage. Coopetition is implemented by SMEs and enables many benefits to these businesses (Akdogan and Cingoz, 2012). SMEs that implement coopetition strategy get into some markets easily by collaborating with each other in different areas and gathering rare resources. SMEs, which engage in competitive strategy share knowledge that may be a key source of competitive advantage (Akdogan and Cingoz, 2012).

Researches on coopetition have focused primarily on larger and multinational businesses (Jorde and Teece, 1990; Luo, 2007). There are limited studies dealing with this phenomenon within SMEs. Questions such as- why small and medium sized businesses chose coopetition and what attitudes they have toward coopetition, need to be addressed. Moreover, it can be also noted that very few studies have addressed this strategy in tourism business generally and in Egypt particularly. Hence, this study will become very useful to fill in this gap that is determined within the intensive literature review.

Therefore, studying this strategy in SMEs in tourism companies (travel agencies and tour operators) currently in Egypt offers many benefits to the business. The risk confronting tourism industry especially in Egypt obliges competing tourism companies to corporate to realize their common goals and to seek for any tool to maximize their efforts and their resources, to be able to struggle against powerful rivals as well as maintain its existence.

Accordingly, the purpose of the present study is to explain coopetition in a theoretical way, and to determine attitudes of small and medium sized businesses dealing with coopetition in the tourism industry in Egypt. It also explores the benefits of implementing coopetition strategy to study the sustainability of tourism industry in Egypt as well as improve their ability to take risks and withstand disasters and catastrophes.

This article is organized as follows: after the introduction, the concept of coopetition and its benefits are presented as well as the related concepts. Secondly, coopetition in SMEs are discussed. The third section presented the importance of implementing coopetition in the tourism industry. The methodological approach, as well as the results and the discussion are then discussed in the fourth and fifth sections respectively..Finally, conclusion and implications of findings are presented. 


\section{Coopetition}

Coopetition is a new kind of strategic relationship between firms involving the merging cooperation and competition. Cooperating to achieve mutual goals, but at the same time competing with each other depending on conflicting benefits (Zineldin, 2004). Firms that prefer this strategy are not solely competitors, but they are also partners. For example, GM and Suzuki comb ining technological resources to manufacture cars, and Siemens and Corning forming a cross-functional alliance to produce and market fiber-optic cables (Laine, 2002).

Firms that intend to use coopetition strategy should consider some conditions to develop mutually beneficial business relationship before getting into a partnership with competitors. Firstly, they are willing to be engaged in interactive exchange relationship. Also, they should have resources that the other party wants. On the other hand, they should want to give up their resources to receive in return the resources belonging to the other organizations. Briefly, each party should understand that this type of strategy will add value to the firm (Zineldin, 2004). According to Morris et al. (2007), coopetition has three key dimensions: mutual benefit, trust, and commitment. Benefits can derive both competition and cooperation. The difference is that the competitive side of relationship does not require a mutuality of benefit, while the cooperative side cannot occur without mutual benefit (Morris et al., 2007). Trust is very important in mutual confidence between firms. With coopetition, a partner develops trust regarding how the other firm will share resources, communicate, use information, and other aspects of the cooperative dimension of relationship (Morris et al., 2007). Commitment is defined as the desire to go on a valued relationship. Commitment entails a process of mutual adaptation, as two parties adjust their expectation, communication approaches, operations, internal processes, and/or approaches to resource allocation to reflect one another's needs, characteristics and requirements (Morris et al., 2007).

A feature of a coopetitive relationship is that partners adapt their processes and products to eliminating or minimizing the sources of insecurity and uncertainty. As a determinant of commitment dimension, this function leads to higher level of trust for creating and enhancing an ongoing strategic business relationship (Zineldin, 2004). On the other hand, trust is a necessary determinant of commitment levels too. When partners trust each other and have high levels of commitment, it is easier for them to adapt to the necessities of the relationship. Mutual benefit also influences relationship commitment. Firms will commit to more involved relationships when they have opportunities for greater benefits, such as lower costs, improved productivity, higher customer satisfaction, and better product performance. Similarly, trust has a positive effect on mutual benefit, which in turn affects relationship success (Morris et al., 2007). So, it is expressed that, all dimensions of coopetition should interact with each other.

Coopetition strategies enable the firms to reach for both competitive and collaborative advantages (Yami et al., 2010). Competition advantages stimulate the search for new combinations of resources, skills and processes. If the firm wants to obtain both types of advantages, it needs to adopt both competitive and cooperative behaviors. 
Coopetition reduces costs, uncertainty, and risks (Laine, 2002; Luo, 2007). From a more strategic point, cooperation with competitors can enhance flexibility of businesses and give businesses more control over market uncertainties (Morris et al., 2007). All in all, coopetition helps firms to acquire rare and new resources, skills and processes. It also improves organizational performance by decreasing cost and providing economies of scale. Firms that adopt the coopetition strategy get into new markets by reducing the risk, and access new opportunities.

On the other hand, coopetition causes some disadvantages for each partner. For instance, Amaldoss et al. (2000) argued that, cooperation between competitors can hinder or delay the process and slow investments in new technologies. Conflict between firms can hamper each company's performance when they attempt to collaborate (Morris et al., 2007). Also, lack of experience in working together with new partners can make considerable demands on management time, attention, efforts and energy, which may lead to neglect of the organization's core business activities (Zeineldin, 2004). A coopetition relationship may cause firms to experience a loss of control over activities or resources. Firms are especially vulnerable when partners become less committed to the cooperative side of the relationship or focus only on their own benefits (Morris et al., 2007). Similarly, if organizations become more dependent on other parties, their vulnerability may increase (Zineldin, 2004).

Relying on different theoretical perspectives, researchers have pointed out that coopetition arises for many strategic reasons. Some researchers argue that coopetition is a firms' response to additional costs (Madhok, 2000). Others suggest that Coopetition could be implemented due to partially overlapped interests (Padula and Dagnino, 2008) between more parties. These parties are tied together by some interdependencies, which create a "value net" between the company and the other market organizations (complements and substitutes). This means that coopetition strategy lead firms to implement win-win strategies rather than win-lose strategies (Brandenburger and Nalebuff, 1995; Schiavone and Simoni, 2011; Dagnino and Mariani 2010)).

Finally, resource based view (RBV) scholars explain coopetition as the need for firms to access resources otherwise difficult to obtain (Hamel et al., 1989; Hamel, 1991; Lavie, 2006; Carayannis et al. 2014).Therefore, companies act in a competition strategy in pursuit of scarce environmental resources and opportunities. Firms form networks with other organizations and eventually competitors to increase their probability of success (Schiavone and Simoni 2011).

There are numerous ways to approach coopetition. Coopetition can emerge between firms at a dyadic (firm to firm) (Bengtsson and Kock, 2000).For Bengtsson and Kock (2003) ' a coopetitive dyadic relationship is established, for example, when two competitors cooperate with each other in a strategic alliance for product development and at the same time compete with each other in the marketing of the products". In other words, they consider coopetition in the context of a supply chain. Cooperation is in the upstream parts of the supply chain and competition is in the downstream parts of the supply chain 
(Walley, 2007). Luo (2004)defines that the aim of coopetition is "to create a bigger business piewhile competing to divide it up'.

Coopetition has been also defined as multi-faceted relationships in a value-net of customers, suppliers, complementorsand competitors (Brandenburger andNalebuff, 1996). Multi-faceted (network levels) coopetition is established, if there are also other participants involved, such as customers, public organizations, suppliers or other stakeholders involved in the coopetition network or "value net" (Brandenburger and Nalebuff,1996; Luo, 2004; Walley, 2007), and relate to one level (simple coopetition) or more levels (complex coopetition) of firms value chains at the same time (Dagnino and Padula, 2002).

The more a firm is powerful and embedded within its network, the more its coopetitors are likely to be interested in its collaboration, the more its competitive strategy is affected. The concept of coopetition has been used in different branches and cases, for example in the context of opera houses (Mariani, 2007), insurance companies (Okura,2007), soft drinks (BonelandRocco, 2007), automobiles (Brandes, et al. 2007), knowledge sharing and innovations in R\&D work (Gnyawali et al., 2006;SoekijadandAndriessen, 2003), military forces (Depeyre and Dumez, 2008), steel industry (Gnyawali et al., 2006) and personal networking (Michailova and Worm, 2003).Gimeno (2004) studied coopetition in airlines. He showed that in global airline industry companies engage with rivals cospecialized alliances in order to implement a "competitive exclusion" strategy against third rivals that could benefit of partners resources. This strategy encourages third rivals to establish "countervailing alliances that replicate the network benefits by enlisting similar (but not the same) partners",(p.825).

Coopetition had been used to a limited extent, in tourism (Michael, 2007; von FriendrichsGra"ngsjo", 2003).

However, recently the complexity of the concept and the practice of coopetition have been of great importance. Indeed, coopetition does not only occuron the basis of intentional and strictly pre-planned decision making but may take unintentional, and therefore also rather tacit, implicit forms (Mariani, 2007, 2009; Rusko, 2008; Walley, 2007).

Coopetition and related concepts: One of the main motives for firms to practice cooperation with competitors is to create greater value or benefit, that is, to improve the performance of the firms. Luo $(2004$, p. 9), for example, emphasizes value creation in the context of coopetition, the goal of which is "to create a bigger business pie, while competing to divide it up". Walley (2007,p. 12) emphasizes the possibility that the benefit is not directed only to the coopetitive firms, but also to the customers.

There are, however, limitations to both paradigms: the competitive paradigm and the cooperative paradigm; the competitive paradigm underestimates the importance of the positive interdependences of cooperation (Brandenburger and Nalebuff, 1996), whereas the cooperative paradigm underestimates the importance of the negative interdependences of cooperation (Padula and Dagnino, 2007). Padula and Dagnino (2007, p. 48) that coopetition provides a more realistic view of the unfolding cooperative relationships. It is also possible to define competition as win-lose/lose-win game (Brandenburger and Nalebuff, 1996)], where an increase in individual profit comes only at the expense of rival firms; cooperation as a win-win game achieving mutual benefits; 
coopetition is considered a win-win-win game (Walley, 2007)] because it includes both of these characteristics simultaneously (Padula and Dagnino, 2007; Okura, 2007,p. 56).Hence, it is important to study the exact position of coopetition between cooperation and competition. As illustrated in Figure 1, the cooperative paradigm involves several different forms of cooperation: collusion (a cartel), and strategic alliances and their differences to and relationship with coopetition. Collusion is very close to coopetition. However, it is possible to distinguish between these two concepts. In collusion, competing firms collaborate with each other and for that reason collusion involves part of the coopetition definition. However, in collusion the benefit goes to firms by way of the increasing producer surplus through rises in price and the power of monopoly, and consumers are penalized by the decreasing consumer surplus. As a result, there is a decrease in total surplus or social welfare. Walley (2007, p. 16) distinguishes between collusion and the core of coopetition: "[W] here firms cooperate not just to their mutual benefit but also to the benefit of the consumer, the relationship is not collusive. In this instance, 'coopetitive' collaboration has produced a 'win-win-win' situation."

The distinction between the concepts of strategic alliance and coopetition is also addressed. Jorde and Teece (1990) have defined such alliances characterized by the commitment of two or more partner firms to a common goal. It is evident that in their thinking the strategic alliance is nearer to cooperation than competition.

In addition, a distinction can be drawn between the concepts of strategic alliance and collusion. In collusion, the competing firms collaborate using price or the quantity of production as a strategic variable. At the same time, they compete in other strategic variables. Thus, collusion always involves competitive aspects, which is not necessary the case for a strategic alliance (Rusko, 2011b).

A strategic alliance is coopetitive if it includes competitive moves, and collusion is coopetitive if the firms involved compete with regard to at least one strategic variable (e.g., quality, or flexibility). In other words, firms can engage in collusion and a strategic alliance at the same time. The general difference between these concepts is that in strategic alliances the degree of cooperation is higher than in coopetition, whereas in cartels or collusions the degree of competition is higher than in coopetition (see Fig. 1). 


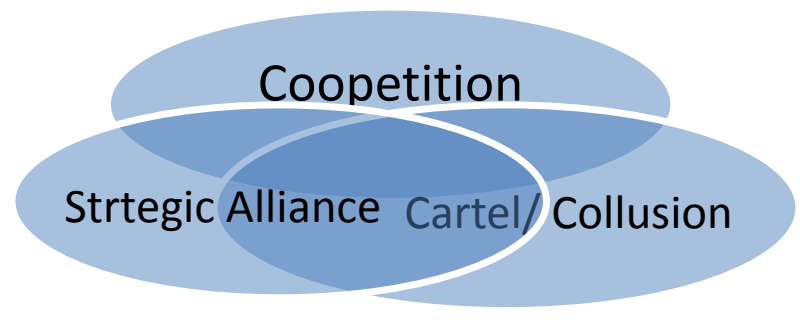

\section{Cooperation}

Degree of Cooperation
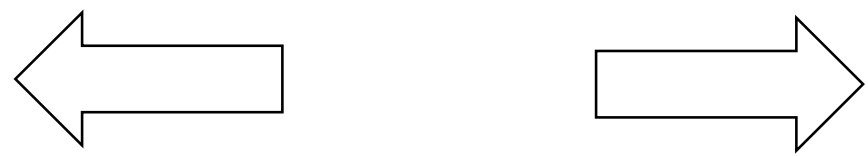

Degree of Competition

\section{Competition}

Figure 1: Typical relationships between the strategic alliance, coopetition and collusion Source: Rusko (2011b), p.312.

\section{Coopetition strategy in SMEs}

Coopetition strategy is generally used by large companies to increase their power(Jorde and Teece, 1990; Luo, 2007). Nevertheless, coopetition is also a useful strategy for small and medium sized businesses (SMEs) too. Coopetition is useful for small and medium sized businesses in certain areas such as; lowering costs, entering bigger market, acquiring bigger share in the market, as well as benefiting from technological development and scale economies (Kock, et al. 2010).

Comparing with larger firms, small and medium sized businesses have some weaknesses. They are more vulnerable and sensitive to environmental forces. Moreover, they have limited cash reserves (Morris et al., 2007). Organizational capacity of SMEs is limited; they have trouble to access some resources. They have also small market shares, few major customers, and they are unable to influence price (Levy et al., 2003).Market uncertainty is usually strong for SMEs.

Hence, it has become very important for small and medium sized businesses to be engaged in a certain relationship such as strategic alliance or to use coopetition strategy to be stronger against fierce rivals. Businesses that chose coopetition strategy get into some markets easily by collaborating with competitors in different areas and gathering complementary resources (Akdogan and Cingoz, 2012).

Relationships with competitors can allow the firm to develop or use technologies that it otherwise could not develop on its own (Morris et al., 2007: p. 39). (SMEs) businesses that engage in coopetition strategy share knowledge that may be a key source of competitive advantage (Levy et al., 2003). Dynamic, hostile, and complex environmental conditions also result in an increased emphasis on innovation as a 
source of competitive advantage (Morris et al., 2007). So, (SMEs) can prefer to develop collaborative relationships with competitors.

\section{Coopetition strategy in tourism}

All industries are interested in risk reduction, and maximizing revenues. However, this need may be more acute in tourism industry for the following reasons: The tourism product is perishable; people are inseparable from the production-consumption process; customer satisfaction depends on different services; tourism demand is extremely sensitive to economic, social, political and environmental circumstances; and finally tourism supply requires large, long lead-time investments in equipments, and infrastructures. Moreover, tourism industry faces many challenges that increase risks which prevent the industry to achieve their goals. Therefore, the ability of tourism industry to adopt the changes will determine its success and its sustainability or even survival. As a result of these new conditions, implementing coopetition in tourism industry will be beneficial in marketing, reducing costs, enhancing service quality, and thus increasing tourist satisfaction.

Tourism industry as a service industry involves complex networks. In a location-based tourism business, production and consumption take place on several inter connected levels simultaneously; an international level, a national level, a regional level and a local level, but at the same time on levels of a tourism enterprise, an individual worker, and on the level of customer encounters (Krakover, (2008), and Rusko, (2011a,b)).

Tourism goes as a fertile example of services in which interaction between public and private sectors is important and clear. Moreover, Tourism product is a complicated product. It implies the integration between many several services (transportation, accommodation, entertainment, food and beverages, etc.). Therefore, coopetition strategy will be effective and beneficial in the tourism industry.

The way, in which coopetition processes between enterprises, semi-public development organizations and public sector have been organized in a tourism destination, reveals important relationship structures and dynamics of contemporary service branches. Thus, tourism industry provides a good case to understand organizing of business processes in a complex operational environment. By combining this multi-level environment with the coopetition argument and framework, emphasizing both intentional and unintentional forms of coopetition, it can be provided new contributions into the debate of organized and emerging coopetition processes (Rusko, 2011a).

Recently, Egypt has experienced several crises which negatively affected tourists' volume. For, example, the global economic crisis in 2008 has affected the number of tourists coming to Egypt. In 2009, the change rate in tourist arrivals has decreased by $2.3 \%$, and the tourism nights have decreased by $-2.1 \%$. Furthermore; the revolution of $25^{\text {th }}$ January 2011 has also affected tourism industry. The change rate in tourist arrivals has decreased by $-33.1 \%$, and the tourism nights have decreased by $-22.8 \%$ in 2012 (World Tourism Barometer, 2013). Tourism in Egypt seeks for any tool which 
Can minimize the negative effects of these additional challenges as well as the common challenges confronting tourism industry in this competitive environment.

\section{Methodology}

In this study we aim to examine the attitudes of small and medium sized tourism businesses in Egypt related with coopetition, as well as coopetition strategy benefits, aspects and disadvantages. To achieve this aim a field survey was conducted using structured questionnaires which were distributed to key- persons of small and medium sized tourism businesses operating in Alexandria, Egypt.

All businesses in the sample employ less than 250 employees. In the literature, a small and medium sized business is defined as business that works 250 and less than 250 employees (Akdogan and Cingoz, 2012).

The study started from $1^{\text {st }}$ of December 2014 and took about one month and a half to distribute and collect questionnaires. Questionnaires were distributed to a sample of 100 main branches of tourism companies (tourism travel agencies and tour operators) in Alexandria, Egypt. Questionnaires were divided into five sections, section one is concerned with some characteristics about the company, section two is devoted to the attitudes of these companies related to coopetition, section three and four investigated coopetition dimensions which are: trust, commitment and benefits as well as its disadvantages respectively. The fifth section addressed the coopetition aspects. And finally, challenges confronting coopetition practice is required.

Based on the previous discussed coopetition literature, questionnaires were first developed. It was also reviewed by academic colleagues to ensure its validity and clarity. Their feedback was used to modify the questionnaire and to refine its measures and instructions. A pilot study was also conducted, and the reliability and validity of the questionnaires were tested. Reliability can be thought of as a consistency in measurement. The overall response rate was approximately 52\% (52usable questionnaires), which is acceptable for this kind of study. Measures were indicated on a 5-point scale with an agree/disagree continuum (1 strongly disagree, to 5 strongly agree).

Data was then coded and analyzed using the Statistical Package for Social Sciences (SPSS). Descriptive analysis was used to recognize the characteristics of the tourism companies.

Moreover, means and standard deviations for each variable as well as Pearson correlation coefficient were also calculated to test the relationships between variables. In addition the one sample t-test was also used to identify the significance mean difference of questiotionnaire's variables. To establish the reliability of the questionnaire Cronbach's alpha was calculated. The scale was found to be internally reliable (Cronbach's alpha= $0.869)$. 


\section{Results and Discussion}

$39.7 \%$ of tourism companies, employee range from 11 to 50 workers, and $60.3 \%$ of tourism companies, employee range from 2 to 10 workers. Concerning number of branches, $32.2 \%$ of the sample is only one branch, while $42.7 \%$ and $25.1 \%$ of tourism companies had 2 branches or more than 2 branches respectively. Types of businesses vary from hotel bookings, airlines booking, transportation, organizing tourism trips inside and outside Egypt as well as religious tourism trips.

Coopetition score is 4.29 , tourism companies that participated in survey have a positive attitude toward coopetition strategy. That is, their assessment for the collaboration with competitors is positive (more than 3). Minimum score related with coopetition is 4.02 belongs to Past coopetition implementation, in contrast maximum score is 4.7 related to Coopetition practice with similar size company. This implies that key persons do not prefer to implement coopetition strategy with either smaller (they don't prefer to support weaker partner) or bigger size companies (to be dependent and have less power than the other partner in decision making). The significance 2- tailed of all the statements is 0.00 which implies that the dimensions of this section are significant. This means that top managers have positive attitudes towards corporation with competitors.

Table 1. Coopetition practice

\begin{tabular}{|l|l|l|l|}
\hline Coopetition practice & Mean & Std. Deviation & $\begin{array}{l}\text { Significance } \\
\text { 2 tailed }\end{array}$ \\
\hline Past coopetition implementation & 4.02 & 1.102 & 0.00 \\
\hline Competition was at the beginning then coorporation started & 4.12 & 1.012 & 0.00 \\
\hline Coopetition practice with similar size company & 4.7 & 1.007 & 0.00 \\
\hline Implementation intention & 4.24 & 1.106 & 0.00 \\
\hline $\begin{array}{l}\text { preference competitors in collaboration to } \\
\text { competitors without collaboration }\end{array}$ & 4.14 & 1.117 & 0.00 \\
\hline flexibility of coopetition implementation & 4.04 & 0.84 & 0.00 \\
\hline Overall coopetition score & 4.29 & 1.233 & 0.00 \\
\hline
\end{tabular}

Respondents are also required to identify the parties whom they practice coopetition strategy with. The majority $(81.6 \%)$ of the sample identifies domestic tourism companies, $12.1 \%$ identifies international tourism companies, while only $6.3 \%$ identifies tourism companies of the public sector.

Furthermore, the score of trust dimension equals 4.9 (significance 2 - tailed $=0.00$ ), and that of commitment dimension equals 4.03, (significance 2 - tailed $=0.00$ ). This means that trust is the most important factor in relationship with competitors. This is compatible with the literature, as trust is seen very important factor in process of coopetition strategy too (Bengtsson and Kock, 2000). Secondly, commitment is considered also important. According to the respondents, when they start to corporate with their competitors, their partners must be honest and reliable. Also they implied 
that, in such a relationship, internal information must not be used for any other purpose than for the partnership (mean score $=4.21$ ). Similarly, information and resources must be shared with honesty (mean score $=3.95,4.12$ respectively).

In the context of commitment dimension, Companies key persons emphasize the requirement of mutual commitment in relationship (mean score $=4.03$, significance 2tailed $=0.00$ ), particularly, in approaches to resource allocation to reflect one another's needs, characteristics and requirements (mean score $=4.14$, significance 2 - tailed $=0.00$ ), followed by commitment in the readiness to mutual adaptation, adjust our expectation (mean score $=4.12$, significance 2 - tailed $=0.00$ ). This implies the importance of commitment for the success of such a relationship established with competitors.

Mutual benefits dimension has also a significant importance for the establishment of coopetition relationship. Minimum mean score of mutual benefits dimension is 3.1 related to Increase innovation chances, while maximum meanscore is 4.31 , related to reduce costs as well as Increase the resources and capabilities that are needed for competition respectively, which means that companies involved in survey, disagreed about some of mutual benefits which are Increase innovation chances and Attract qualified employee to business (mean scores $=3.1$ and 3.15 respectively). Moreover, firms can implement coopetition to improve its present performances, achieve critical competitive advantages, as well as to recognizing new opportunities and developing new products. From a strategic point of view coopetition can enhance flexibility of businesses (mean score $=$ 4.11). These results are compatible with Hamel (1991) and Morris et al. (2007). Hamel (1991) who studied nine international alliances between competitors reported that the primary objective of firms was to get benefit of partner skills. Morris et al. (2007) stated that cooperation with competitors can enhance flexibility of businesses and give businesses more control over market uncertainties.

Table 2: Mean and standard deviation of Coopetition Dimension

\begin{tabular}{|l|l|l|l|}
\hline \multicolumn{1}{|l|}{} & Mean & $\begin{array}{l}\text { Std. } \\
\text { Deviation }\end{array}$ & $\begin{array}{l}\text { Significance } \\
\text { 2 tailed }\end{array}$ \\
\hline Trust is a very important condition to implement coopetition & 4.9 & 1.12 & 0.00 \\
\hline $\begin{array}{l}\text { Trust is a very important condition to implement coopetition } \\
\text { especially in sharing resources }\end{array}$ & 4.12 & 1.003 & 0.001 \\
\hline $\begin{array}{l}\text { Trust is a very important condition to implement coopetition } \\
\text { especially in sharing information }\end{array}$ & 3.95 & 1.007 & 0.00 \\
\hline $\begin{array}{l}\text { Trust is a very important condition to implement coopetition } \\
\text { especially in using information }\end{array}$ & 4.21 & 1.106 & 0.00 \\
\hline Commitment is a very important condition to implement coopetition & 4.03 & 1.117 & 0.00 \\
\hline $\begin{array}{l}\text { Commitment is a very important condition to implement coopetition } \\
\text { especially in our readiness to mutual adaptation, adjust our } \\
\text { expectation }\end{array}$ & 4.12 & 0.998 & 0.00 \\
\hline $\begin{array}{l}\text { Commitment is a very important condition to implement coopetition } \\
\text { especially in communication approaches }\end{array}$ & 3.29 & 1.233 & 0.003 \\
\hline
\end{tabular}




\begin{tabular}{|c|c|c|c|}
\hline $\begin{array}{l}\text { Commitment is a very important condition to implement coopetition } \\
\text { especially in operations, internal processes }\end{array}$ & 3.81 & 1.213 & 0.00 \\
\hline $\begin{array}{l}\text { Commitment is a very important condition to implement coopetition } \\
\text { especially in approaches to resource allocation to reflect one another's } \\
\text { needs, characteristics and requirements }\end{array}$ & 4.14 & 0.985 & 0.00 \\
\hline \multicolumn{4}{|l|}{ Mutual benefits dimension } \\
\hline Get into bigger markets & 4.02 & 1.003 & 0.00 \\
\hline acquire bigger share & 4.13 & 0.899 & 0.00 \\
\hline get more valuable information & 3.55 & 1.102 & 0.001 \\
\hline Get benefit from technological development and scale economies & 3.81 & 1.114 & 0.00 \\
\hline Increase innovation chances & 3.1 & 0.965 & 0.00 \\
\hline Attract qualified employee to business. & 3.15 & 0.982 & 0.00 \\
\hline Reduce costs & 4.31 & 1.105 & 0.00 \\
\hline Enhance the Egyptian tourism product & 4.19 & 1.009 & 0.00 \\
\hline Increase customer satisfaction & 4.24 & 1.132 & 0.00 \\
\hline $\begin{array}{l}\text { Increase the resources and capabilities that are needed for competition } \\
\text { on our own }\end{array}$ & 4.31 & 0.942 & 0.00 \\
\hline $\begin{array}{l}\text { Increase our capability to take all the risks alone to struggle against } \\
\text { powerful rivals }\end{array}$ & 4.26 & 1.114 & 0.00 \\
\hline Enhance flexibility of businesses & 4.11 & 1.129 & 0.00 \\
\hline Give businesses more control over market uncertainties & 3.15 & 1.243 & 0.00 \\
\hline
\end{tabular}

The Pearson correlation coefficient was also used to investigate whether there is a relationship between coopetition implementation and coopetition dimensions. Results showed that there is a significant positive relationship $r=0.747 \mathrm{sig}$. $(2$-tailed $)=0.001$ at 0.01 level of significance. Moreover, there is a significant positive relationship $r=0.716$ sig. $(2$-tailed $)=0.001$ at 0.01 level of significance between the level coopetition implementation and mutual benefits. These results implies the importance of the coopetition dimensions represented in trust, commitment, and mutual benefits as condition to practice coopetition strategy in the Egyptian tourism companies. The previous result agreed with the studies of Zineldin (2004) and Morris, et al. (2007) who confirmed the existence of coopetition dimensions to be engaged in such relationship.

Table 3: One Sample Test for the coopetition practice and coopetition dimensions

\begin{tabular}{|c|c|c|c|c|c|c|}
\hline & \multicolumn{6}{|c|}{ Test Value $=0$} \\
\hline & \multirow[t]{2}{*}{$\mathrm{T}$} & \multirow[t]{2}{*}{ Df } & \multirow[t]{2}{*}{$\begin{array}{ll}\text { Sig. } \\
\text { tailed })\end{array}$} & \multirow[t]{2}{*}{$\begin{array}{l}\text { Mean } \\
\text { Difference }\end{array}$} & \multicolumn{2}{|c|}{$\begin{array}{l}95 \% \text { Confidence Interval of the } \\
\text { Difference }\end{array}$} \\
\hline & & & & & Lower & Upper \\
\hline CoopetionPractice & 24.184 & 48 & .000 & 4.43175 & 4.2291 & 4.6344 \\
\hline Coopetition Dimensions & 28.944 & 48 & .000 & 4.2134 & 3.9856 & 4.4128 \\
\hline
\end{tabular}


Table 3 shows that there is not a significance difference between different means of the coopetition implementation and coopetition conditions which implies that there is no significantly difference in means, which subsequently means that all the respondents agree that coopetition strategy is implemented in Egyptian tourism companies. Furthermore, they do agree that the coopetition conditions (trust, commitment and mutual benefits) are important for them to implement coopetition strategy.

Table 4: Mean and standard deviation of Coopetition disadvantages

\begin{tabular}{|l|l|l|l|}
\hline Coopetition disadvantages & Mean & $\begin{array}{l}\text { Std. } \\
\text { Deviation }\end{array}$ & $\begin{array}{l}\text { Significance } \\
\text { 2- tailed }\end{array}$ \\
\hline Hinder or delay the innovation process & 1.93 & 1.325 & 0.00 \\
\hline Slow investments in new technologies & 1.89 & 1.217 & 0.00 \\
\hline $\begin{array}{l}\text { Hamper each company' s performance when they } \\
\text { attempt to collaborate }\end{array}$ & 1.98 & 1.007 & 0.001 \\
\hline $\begin{array}{l}\text { Make considerable demands on management time, } \\
\text { attention, efforts and energy, which may lead to } \\
\text { neglect of the organization's core business activities }\end{array}$ & 1.106 & 0.00 \\
\hline $\begin{array}{l}\text { Cause firms to experience a loss of control over } \\
\text { activities or resources }\end{array}$ & 1.98 & 1.117 & 0.001 \\
\hline $\begin{array}{l}\text { Increase vulnerability if organizations become more } \\
\text { dependent on other parties. }\end{array}$ & 2.98 & 1.321 & 0.00 \\
\hline
\end{tabular}

Conversely, Respondents don't agree about coopetition disadvantages, the mean of all the disadvantages are less than 3 , which implies that respondents believe that coopetition has no negative impact on their business. These results contradict with Amaldoss et al. (2000) who argued that coopetition can delay the innovation process and slow investments in new technologies, as well as Morris et al. (2007) who stated that coopetition relationship may cause firms to experience a loss of control over activities or resources. The results also disagree with Zeineldin (2004) who stated that coopetition can make considerable demands on management time, attention, efforts and energy, which may lead to neglect of the organization's core business activities.

Table 5: Coopetition aspects

\begin{tabular}{|l|l|l|}
\hline Coopetition aspects & Mean & Std. Deviation \\
\hline During marketing & 3.98 & 1.002 \\
\hline During product development and competency & 4.32 & 1.121 \\
\hline During the operation process & 4.13 & 1.007 \\
\hline
\end{tabular}


Concerning coopetition implementation aspects, respondents stated that they do implement coopetition to develop their product and enhance its quality to increase customer satisfaction and during the operation process (mean score $=4.32$ and 4.13 respectively). It is notable here that operational level (e.g. get-togethers and meetings, more or less mundane decisions on marketing campaigns, website updates and weekly or monthly communications) which implies that respondents identify the level of cooperation to be high in the case of competition with rivals without closeness to customers (upstream coopetition), and the level of competition is higher with closeness to consumers market (downstream coopetition).

Concerning the challenges, respondents focused on the importance of government in supporting tourism industries by being engaged in such relationships in many forms, such as membership of joint organizations, joint research, as well as being supportive of such alliances. The role of government and institutions has been, and still is, one of the main characteristics affecting the development of the tourism industry in Egypt. The cooperation between the tourism industry and the government has been so intense that even tightening competition legislation, the Egyptian government has had the role of supporting and coordinating such relationships. Moreover, they stressed on the importance of trust to be able to achieve the expected benefits of this strategy as a major challenge confronting coopetition practice.

\section{Conclusions and implications}

This study emphasizes the importance of coopetition strategy in tourism industry in Egypt, as well as the ways of thinking, the actual activities taken and expected benefits, in another word the overall coopetitive culture.

The discussion of managerial implication is based on three levels: policy, industry, and firm.

The empirical study shows that tourism companies have a positive attitude towards coopetition; they also tend to practice coopetition strategy in business. It also shows the high level of coopetition in the tourism industry is accompanied by a value increment, either by lower costs or by enhancing service quality without additional costs and subsequently enhancing tourist satisfaction. In addition, the study shows the variation in the coopetition application in the tourism industry in different aspects either in marketing, or during product or service development and competency, as well as timing of coopetitive actions within the tourism industry.

At the policy level the managers' implication is the need to pay more attention to the importance of government in supporting such strategic alliances and relationships.

The study also has motivating industry-level managerial implications. In the era of globalization, firms are tempted to compete with each other without questing for opportunities said to be afforded by cooperation and coopetition, which might reduce the overall performance of the tourism industry sector.

At the firm level the most significant implication related to agility, i.e. how fast the firms are able to adapt their strategic cooperation and other strategic activities for the needs of a turbulent business environment. Fundamental activities such as sales, or acquisitions, could be the only strategic alternative to maintain the business. Thus, firms should also be ready for fundamental changes, such as breaking up or selling a company. This kind of 
agility may guarantee that both the firm and the industry also survive during recessions. Coopetition practice in tourism companies in Egypt is in marketing and competencies. Strategic development should be considered to increase their readiness to fundamental changes and risks, as well as to be able to survive during recessions. In other words, implementing coopetition strategy helps in turning the distinct, single tourism services into a solid destination product.

\section{References}

- Akdogan, A.A., and Cingoz, A. (2012). "An empirical study on determining the attitudes of small and medium sized businesses (SMEs) related to coopetition”. Procedia - Social and Behavioral Sciences, Vol. 58, pp. 252 258.

- Amaldoss, W. et al. (2000).“Collaborating to compete”. Marketing Science, Vol.19, No.2, pp.105-126.

- Bengtsson, M., and Kock, S. (2000). "Coopetition" in business networks - To cooperate and compete simultaneously. Industrial Marketing Management, Vol. 29, No. 5, pp.411-426.

- Bengtsson, M., and Kock, S. (2003). "Tension in co-opetition". Academy of Marketing Science, Annual Conference, May, pp. 28-31,Washington, D.C.

- Bonel, E., and Rocco, E. (2007). "Coopeting to survive; surviving coopetition". International Studies of Management and Organization, Vol. 37, No. 2, pp.70-96.

- Brandenburger, A.M. and Nalebuff, B.J. (1995) "The right game: use game theory to shape strategy". Harvard Business Review, July-August, pp. 57-71.

- Brandenburger, A. M., and Nalebuff, B. J. (1996). "Co-opetition”. New York: Doubleday Currency.

- Brandes, O., Brege, S., Brehmer, P.-O. and Lilliecreutz, J. (2007). "Chambre Separee_ in product development: Vertically mediated coopetition in the automotive supply chain". Journal of Automotive Technology and Management, Vol. 7, No. 2-3, pp.168-183.

- Carayannis, E. G., Depeige, A. and Sindakis, S., (2014). "Dynamics of ultra-organizational co-opetition and circuits of knowledge: a knowledge-based view of value ecology", Journal of Knowledge Management, Vol. 18, Iss 5, pp. $1020-1035$.

- Chesbrough, H.W., Vanhaverbeke, W. and West, J. (2006). "Open Innovation: Researching aNew Paradigm". Oxford University Press, New York, NY.

- Dagnino, G. B. and Padula, G. (2002). "Coopetition strategy - A new kind of interfirm dynamics for value creation". Paper presented at the EURAM conference "Innovative research in management". Stockholm, Sweden, May 9-11.

- Dagnino, G.B., and Mariani, M.M. (2010). "Coopetitive value creation in entrepreneurial contexts: an applied interpretative framework". In: Yami, S., Castaldo, S., Dagnino, G.B., Le Roy, F., Czakon, W. (Eds.), Coopetition: Winning Strategies for the $21^{\text {st }}$ Century. Edward Elgar, Cheltenham, pp. 101-123.

- Depeyre, C. and Dumez, H. (2008). "A management perspective on market dynamics: Stabilizing and destabilizing strategies in the US defense industry". European Management Journal, Vol. 27, No. 2, pp. 90-99.

- Gimeno, J. (2004). "Competition within and between networks: the contingent effect of embeddedness on alliance formation", Academy of Management Journal, Vol. 47 No. 6,pp. 820-42.

- Gnyawali, D.R., He, J. and Madhavan, R. (2006). "Impact of co-opetition on firm competitive behavior: an empirical examination". Journal of Management, Vol. 32 No. 4, pp. 507-30.

- Hamel, G. (1991). "Competition for competence and inter-partner learning within international strategic alliances". Strategic Management Journal, Vol. 12, pp. 83-103.

- Hamel, G., Doz, Y.L. and Prahalad, C.K. (1989) "Collaborate with your competitors and win".Harvard Business Review, Vol. 1, pp. 133-9.

- Jorde, T.M., and Teece, D.J. (1990). "Innovation and cooperation: Implications forcompetition and antitrust". Journal of Economic Perspective, Vol.4, No.3, pp.5-96.

- Kock, S., Nisuls, J. and Söderqvist, A. (2010)."Co-opetition: a source of international opportunities in Finnish SMEs", Competitiveness Review: An International Business Journal, Vol. 20, Iss 2 pp. 111 - 125.

- Krakover, S. (2008), "Destination marketing: competition, cooperation or coopetition?", International Journal of Contemporary Hospitality Management, Vol. 20, Iss 2, pp. $126-141$.

- Laine, A. (2002)."Hand in hand with the enemy: Defining a competitor from a new perspective". EURAMInnovative Research inManagement Stockholm, Sweden, May 9-12, pp. 1-10. 
- Lavie, D. (2006). "The competitive advantage of interconnected firms: an extension of theresource-based view". Academy of Management Review, Vol. 31 No. 3, pp. 638-58.

- Levy, M., Loebbecke, C. and Powell, P. (2003).“SMEs, Co-opetition and knowledge sharing: The role of information systems".European Journal of Information Systems, Vol. 12, pp. 3-17.

- Luo, Y. (2004). "Coopetition in international business". Copenhagen Business School Press.

- Luo, Y. (2007). A coopetition perspective of global competition. Journal of World Business, Vol.42, No.2, pp.129-144.

- Mariani, M. M. (2007). "Coopetition as an emergent strategy". International Studies of Management \& Organization, Vol.37, No.2, pp.97-126.

- Michael, E. J. (2007). "Micro-clusters: Antiques, retailing and business practice", In Micro- clusters and tourism. The growth of tourism, (ed) E. J. Michael, pp. 63-78. Advanced in tourism research series. Oxford: Elsevier.

- Michailova, S. and Worm, V. (2003) Personal networking in Russia and China: Blat and Guanxi. European Management Journal 21(4), 509-519.

- Morris, M. H., Kocak, A. and Ozer, A. (2007). "Coopetition as a small business strategy: Implications for performance". Journal of Small Business Strategy, Vol.18, No. 1, pp.35-55.

- Okura, M. (2007). "Coopetitive strategies of Japanese insurance firms". International Studies of Management \& Organization, Vol.37, No.2, pp.53-69.

- Padula, G., and Dagnino, G. B. (2007). "Untangling the rise of coopetition". International Studies and Management \& Organization, Vol.37, No.2, pp.32-52.

- Padula, G. and Dagnino, G.B. (2008). "Untangling the rise of coopetition: the intrusion of competition in a cooperative game structure", International Studies of Management and Organization, Vol. 37, No. 2, pp. 32-52.

- Rusko, R. (2008). "Unintentional coopetition and supply chain management", In Proceedings of the 13th international conference on productivity and quality research ICPQR2008, (eds) J. Kujala and P. Iskanius, pp. 642-653. Oulu, Finland, 25-27 June.

- Rusko, R. (2011a). "Unintentional coopetition in the service industries: The case of Pyha"-Luosto tourism destination in the Finnish Lapland Mika Kyla“nen”. European Management Journal, Vol 29, pp.193-205.

- Rusko, R. (2011b), "Exploring the concept of coopetition: A typology for the strategic moves of the Finnish forest industry". Industrial Marketing Management, Vol.40, pp.311-320.

- Saraniemi, S. and Kyla"nen, M. (2010). "Problematizing the concept of tourism destination: An analysis of different theoretical approaches". Journal of Travel Research XX(X), pp. 1-11 [<http://jtr.sagepub.com/cgi/content/abstract/0047287510362775v1>. Accessed 29 December 2014].

- Schiavone, F. and Simoni, M. , (2011),"An experience-based view of co-opetition in R\&D networks", European Journal of Innovation Management, Vol. 14 Iss 2 pp. 136 - 154.

- Soekijad, M. and Andriessen, E. (2003) Conditions for knowledge sharing in competitive alliances. European Management Journal 21(5), 578-587.

- VonFriendrichs, and Gra“ngsjo“, Y. (2003). "Destination networking: Coopetition in peripheral surroundings". International Journal of Physical Distribution and Logistics Management, Vol. 33, No. 5, pp.427-448.

- Walley, K. (2007). :Coopetition. An introduction to the subject and an agenda for research”. International Studies and Management \& Organization, Vol. 37, No. 2, pp.11-31.

- World Tourism Barometer (2013), World Tourism Barometer, Volume 10, March.

- Yami, S., Castaldo, S., Dagnino, G.B., Le Roy, F., and Czakon, W. (Eds.), (2010). "Coopetition:Winning Strategies for the 21st Century". Edward Elgar, Cheltenham.

- Zineldin, M. (2004). "Co-opetition: the organization of the future, Marketing Intelligence and Planning”, Vol. 22, No. 6/7, pp. 780-789. 